\title{
KÉZTÖRÉSBÖL FELÉPÜLŐ PÁCIENS ERŐNLÉTÉNEK VIZSGÁLATA MEMS SZENZOR SEGÍTSÉGÉVEL
}

\section{MONITORING THE CONDITION OF PATIENTS RECOVERING FROM HAND FRACTURE WITH MEMS SENSOR}

\author{
Tóth László ${ }^{1^{*}}$ \\ ${ }^{1}$ Anyagtechnológia Tanszék, GAMF Müszaki és Informatikai Kar, Neumann János Egyetem, Magyarország \\ https://doi.org/10.47833/2020.1.ENG.001
}

\section{Kulcsszavak: \\ szenzor \\ hálózat \\ egészségügy \\ Shimmer}

\section{Keywords:}

sensor

network

health

Shimmer

\section{Cikktörténet:}

Beérkezett 2019. október 29.

Átdolgozva 2020. február 2.

Elfogadva 2020. február 7.

\begin{abstract}
Összefoglalás
A szenzorhálózatok gyors fejlödésével, az egyes élettani folyamatadatok gyüjtésének szüksége miatt, a vezeték nélküli szenzorhálózatok az egészségügyben is egyre inkább elterjedtek. Az alábbi publikáció a Shimmer szenzorhálózatok egészségügyi felhasználását mutatja be egy kéztörés után rehabilitálandó páciensnél. Feladata, a páciens fejlődésének bemutatása a rehabilitáció megkezdése előtt és a rehabilitáció után. A rehabilitáció tenisz segítségével történik. A páciensek által kimutatott fejlődési értékek összehasonlításra kerülnek a klasszikus terápiával kezelt betegekkel, amiböl következtethetünk a terápia eredményességére.

Abstract
With the rapid development of sensor networks and the need to
collect physiological process data, wireless have become
increasingly common in healthcare. The following publication
displays the Shimmer sensor network healthcare use in a
patient's rehabilitation after a broken arm. The task is to present
the patient's development before and after the rehabilitation.
Rehabilitation is done with the help of tennis. The developmental
data obtained by the patients is compared with those treated with
classical therapy, from which the efficacy of the therapy can be
concluded.
\end{abstract}

\section{Bevezetés}

A mai, modern és teljes mértékben felgyorsult társadalmunkban alapvető fontosságú, valamint elvárható, a különféle mozgásszervi megbetegedésekböl való rehabilitáció gyorsabb és hatékonyabb lefolyása, illetve, hogy ne csak egy, a klasszikus megfigyelésen és a gyakorlatok mechanikus értékelésén alapuljon. Fontos az olyan eszközök használata, amelyek segítségével képesek vagyunk kvantitatív mennyiségek akár folyamatos mérésére is, ezáltal azonnali visszajelzést kapjunk a páciens teljesítményéröl. A célunk az, hogy ezek a lemért értékek könnyen és gyorsan a rendelkezésünkre álljanak, így gyors és hatékony elemzésre leszünk képesek.

Természetesen a rehabilitációs szakember személyét nem lehet egy eszközzel helyettesíteni, de megkönnyítik, meggyorsítják és kiegészítik munkájukat. Szükség van a rehabilitációs

\footnotetext{
* Tóth László. Tel.: +36 76516334

E-mail cím: toth.laszlo@gamf.uni-neumann.hu
} 
gyógytornász szakemberek tudására és tapasztalatára, de ezek az elektronikus eszközök hozzásegítik öket egy még objektívebb, pontosabb rehabilitációs eseményt megvalósításához, értékeléséhez. Ez abból adódik, hogy egy jól megválasztott és kellően pontos müszer olyan apró technikai részletek kimutatására is képes lehet, amelyeket esetleg a rehabilitációs gyógytornász szakember figyelmét elkerülné és esetleg csak egy lassított videófelvételen venné észre. Ennek elemzése viszont igen lassú, költséges és egyáltalán nem hatékony. Emellett a rögzített, időben hosszabb távú mért adatsorok olyan statisztikai jellegủ információkat adnak a rehabilitáció során, melyek egyéb módszerekkel nehezen megfigyelhetőek. llyenek például, az ütés egyenletessége, a fáradás, stb. Mivel a fejlődés sokszor tized, sőt század másodpercekben mérhetők, ezért bármilyen apró technikai javulás jelentős lehet a fejlődésben valamint a végeredményben.

A fentiek mellett arra a kérdésre keressük a választ, hogy tenisz segítségével valóban hatékonyabban rehabilitálhatók-e a neuromotorikus betegségben szenvedő páciensek, mint az eddigi, klasszikus gyógyterápiák segítségével. A klasszikus terápia eredményességének mértékét egy szakorvos és egy terápiás szakember határozta meg.

$A z$ egységügy hatékonyabbá tételére irányuló kutatások már felkeltették az emberek érdeklödését és többféle publikáció is született hasonló témában. A betegek klinikai állapotának kis mértékü változásának felismerésére vonatkozó sikeres kutatásokat végzett $O$. Chipara[1] és J.Ko [2]. Másik hasonló kutatás a súlyos, akár elemi katasztrófák esetén a páciensek ellátásának sorrendjében történő automatikus sorszámozás D. Malan [3] és T.Gao [4]. Az emberek életének meghosszabbítását megcélzó kutatásokkal, a páciensek életfunkcióinak mobil megfigyelésével foglalkozott G. Virone [5]. Ezen felül tanulmányozásra került az emberi viselkedés és a krónikus betegségek megfigyelése az ember természetes környezetében K. Patrick [6] és S. Kumar [7] által.

\section{A kutatás célja}

A kutatás fő célja alátámasztani azt a feltevést, miszerint a teniszben használatos mozdulatok, illetve maga a tenisz, mint sport jobban hozzájárul-e a neuro-motorikus betegségben szenvedő és ezen betegségekböl felépülő emberek rehabilitációjához és felépüléséhez, mint a klasszikus terápiákon alapuló fejlesztő gyakorlatok. Ezen kívül további cél az informatika, a számítástechnika nagyobb szintű integrációja és bevezetése az egészségügybe, ezáltal fejlesztve annak hatékonyságát.

A megközelítőleg azonos korosztályú, hasonló testfelépítésü és erőnlétű páciensek, klasszikus terápia segítségével átlagosan 40\%-ot fejlődnek a terápia megkezdése előtti állapotukhoz képest. A kutatástól azt az eredményt várjuk, hogy ettől a szinttől magasabb értékeket kapjuk, ami ugyanis egyértelműen bizonyítaná, hogy nagyobb mértékben fejlődött a páciens, mint a klasszikus terápiák esetében és ez a terápia hasznosabb, hatékonyabb mint a klasszikus, eddig használatos terápia.

\section{Shimmer készülék}

Az egészségügyben használatos szenzorok méreteit és súlyát minimalizálni kell, elkerülve így a páciens mozgásának terhelését, megnehezítését. Annak érdekében, hogy ennek az igénynek eleget tegyek, a SHIMMER3 IMU eszközét választottam alapul bemutatásra, hiszen méreteit tekintve igen kicsi $(51 \times 34 \times 14 \mathrm{~mm})$, súlyát tekintve pedig szintén kedvező 23,6g-mal rendelkezik. Kezelhetőségét illetően egyszerü, valamint az árát tekintve sem jelent nagy anyagi megterhelést. $A$ berendezés ezen előnyei mellett még az akkumulátor töltési ideje is igen rövidnek számít más hasonló készülékekhez képest, valamint teljes töltés után, akár 14 napot is képes müködni. [8]

\subsection{Hardver}

A Shimmer3 IMU készülékek központi feldolgozó egysége (CPU) tulajdonképpen egy TI MSP430F5437A típusú, alacsony fogyasztású mikrokontroller, amely vezérli az eszköz müködését. A mikrokontroller beépített 16 csatornás 12 bites analóg-digitális átalakítóval rendelkezik (AD konverter), amelynek az a szerepe, hogy fogadja az inerciális mérőegységektöl (Inertial 
Measurement Units - IMU) érkező jeleket, majd pedig átkonvertálja digitális jellé. İgy például a gyorsulásmérőtől, az akkumulátortól, vagy a szenzorbővítő egységtől stb. A processzor $24 \mathrm{MHz}$-en dolgozik, 16kB RAM belső memóriával rendelkezik, flash memóriája pedig $256 \mathrm{kB}$. Az alaplapon egy foglalat van elhelyezve, a microSD kártya számára, amely az adattárolást szolgálja, az átvitel pedig vezeték nélkül is megvalósítható Bluetooth kapcsolat révén. Lehetőség van a WiFi kapcsolat beépítésére, viszont ilyen esetben szem előtt kell tartani a modul többletfogyasztását. A készülék teljes fogyasztása aktív állapotban $60 \mathrm{~mW}$, míg inaktív helyzetben a fogyasztás néhány mikrowattra csökken, mégpedig az applikáció munkaciklusától függően. [9]

\subsection{Szenzorok}

A Shimmer készülékben különféle szenzorok használatosak, amelyek mind más és más funkciókat töltenek be:

- A gyorsulásmérő egy olyan eszköz, amely a készülék mozgásának gyorsulását méri. Ennek a meghatározásához tudni kell a készülékekre ható eröket, amelyek magukba foglalják, mind a gravitációs erőt, mind az eszköz használata közben jelentkező inerciális erőket egyaránt. A Shimmer eszközök háromtengelyű axiális (triaxiális) gyorsulásmérővel vannak felszerelve, így tehát ezek az eszközök által mért gyorsulásnak három összetevője van az $\mathrm{X}, \mathrm{Y}$ és a $\mathrm{Z}$ tengelyek mindegyikén.

- Sebességmérő giroszkópokkal akár az emberi test szögsebességét is mérni tudjuk. A Shimmer készülékek triaxiális (háromtengelyü) giroszkóppal vannak ellátva, amelyek ezen három tengely irányú szöggyorsulást tudnak mérni.

- Hömérő szenzor, amely az emberi test egyik szegmensének hőmérsékletét méri, majd pedig elemzi az idő függvényében történő változását.

\subsection{Szoftver}

Shimmer készülékek által begyüjtött adatok és az adatok elemzésére, a készülék gyártója által kibocsájtott, Consensys nevü programot használtam, amely müködése és kezelése igen egyszerü (1.ábra).

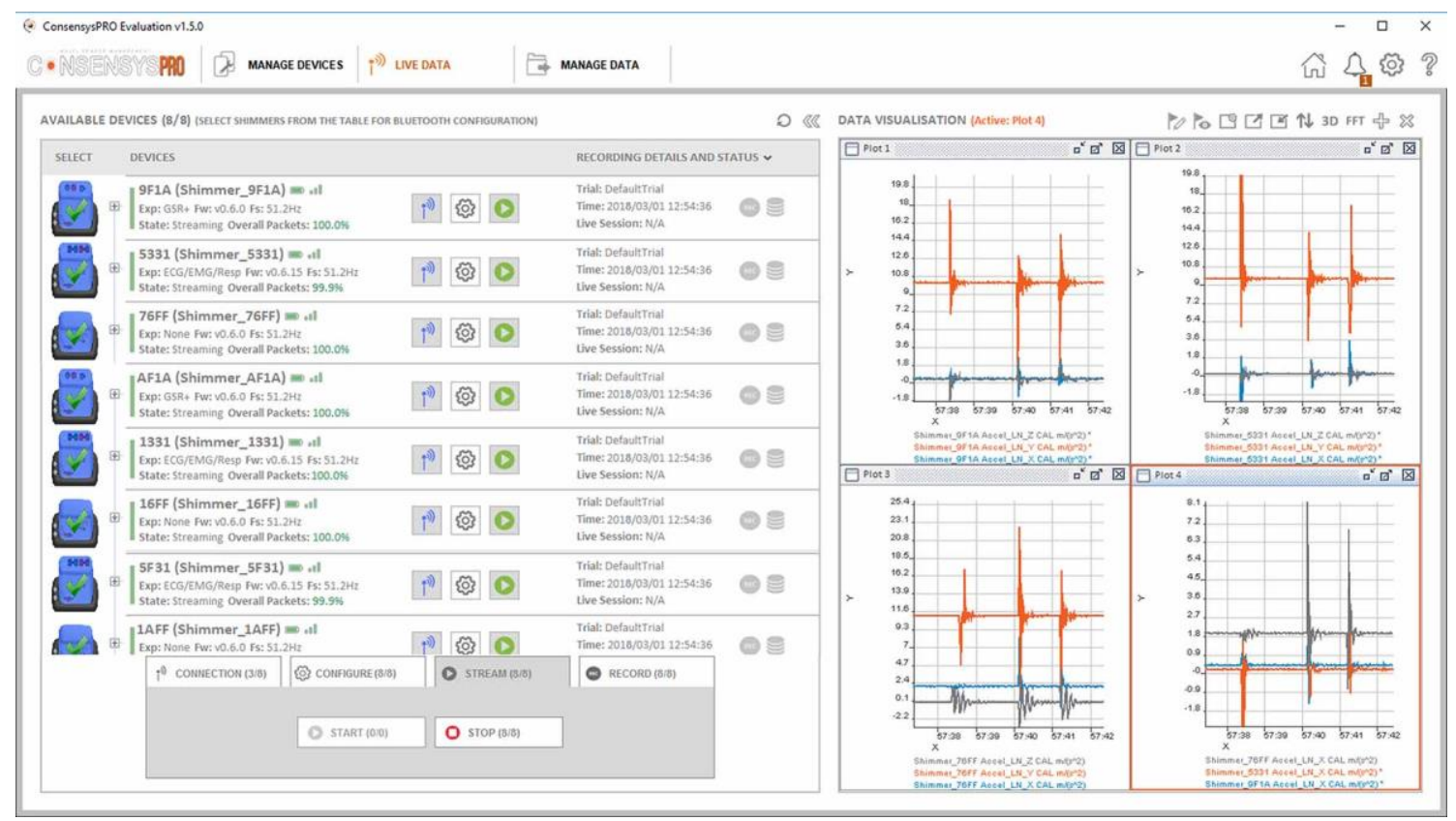

1.ábra: Consensys program kinézete 
A program bal oldali részében találhatók az érzékelök, amelyekröl több adatot is le tudunk olvasni, mint például a jel erőssége, akkumulátor töltöttségi szintje, aktiválni/deaktiválni tudjuk az érzékelöket, stb. A program jobb oldali részében az aktív készülékektöl érkező jeleket láthatjuk az idő függvényében, egy diagramban grafikusan ábrázolva. Ezek a diagramok közül a gyorsulásmérő diagramját használjuk fel az adatok elemzésére, amelyben a függöleges tengelyen található a gyorsulás mértéke $\left(\frac{m}{s^{2}}\right)$, a vízszintes tengelyen pedig a vizsgálat alatt eltelt idő (s). Minden Shimmer eszközök háromtengelyű axiális gyorsulásmérővel van felszerelve (2.ábra), így tehát ezek az eszközök által mért gyorsulásnak három összetevője van az $X, Y$ és a $Z$ tengelyek mindegyikében. Tehát a diagramban megtalálható a három tengelyirány és mindhárom tengelyirányban történő mozgásra való gyorsulás olvasható le. Ezek a tengelyirányok már a készülékben definiálva vannak.

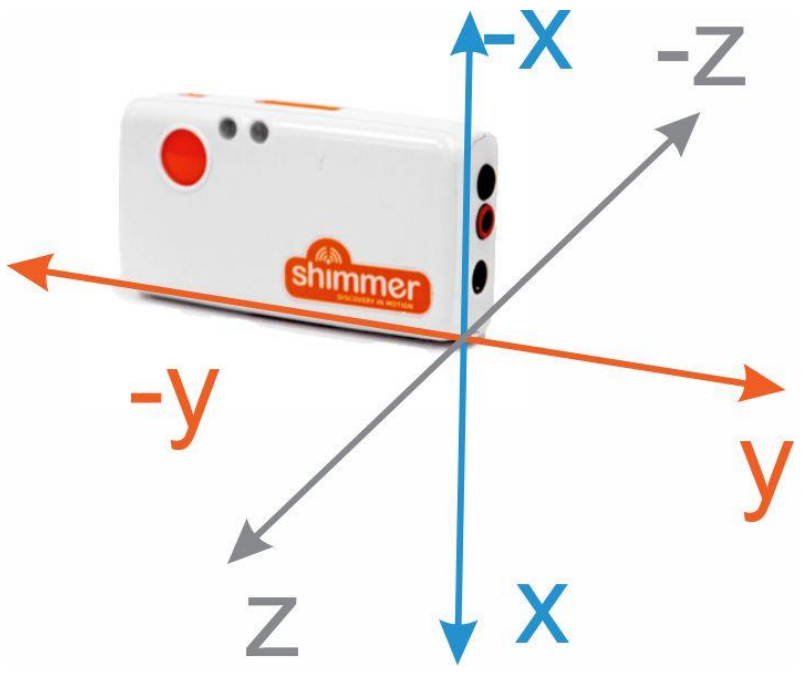

2.ábra: A Shimmer készülékek tengelyirányai

\section{A rendszer kiépítése}

A páciens teljes orvosi elemzéséhez nyolc darab érzékelőt szükséges elhelyezni a betegen, mégpedig minden végtagszegmensre egyet-egyet (3. ábra). Tehát a felkarra, alkarra, combra és a vádlira helyezzük el a készüléket, így egy teljes átfogó képet kaphatunk a páciens testében bekövetkező változásról, fejlődésről. Mivel a kutatás kizárólag informatikai szemszögből elemzi az eredményességet és nem orvosi szemszögböl, így nem kerül elemzésre mind a nyolc érzékelöröl, csak a páciens ütőt tartó csuklóján levő készülékröl, hiszen ennek az egy szenzornak a gyorsulásváltozásával már látható a terápia eredményessége. Már ennek az egy érzékelőnek az elemzésével is látható képet kapunk a páciensek ütésének változásáról a terápia elején és végén. $\mathrm{Ha}$ a páciens jobbkezes, akkor a jobb csuklóján levő, ha balkezes, akkor a bal csuklóján levő készülék kerül elemzésre. 


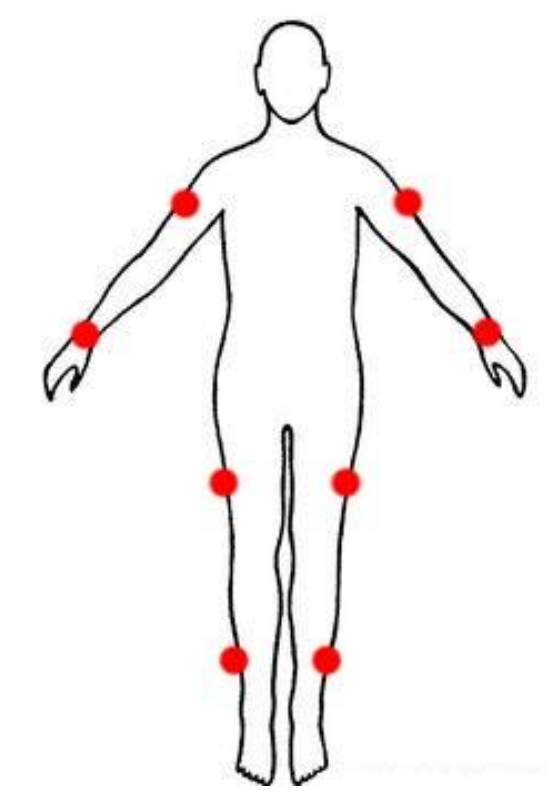

3.ábra: A készülékek elhelyezése

\section{Kutatás}

Azért, hogy a kutatást legálisan és törvényes keretek között bonyolítsuk le, a kutatásban résztvevő személy önkéntes alapon jelentkezhetett és vehetett részt benne. Természetesen a kutatásba nem tartozott bele, hogy megtanuljon teniszezni, így olyan személy jelentkezhetett a kutatásba, aki már ismeri ezt a sportot, vagy ehhez nagy mértékben hasonló sportot, mint például az asztaliteniszt, vagy a squash-t. A kutatás teljes mértékben anonim, igy egy sorszámot kapott. A továbbiakban ezen sorszám alapján azonosítottam őket. Az alábbi, kutatásban résztvevő páciens sorszáma 35. Az alany egy 52 éves férfi, átlagos testalkattal, átlagos súllyal, kéztöréses sérüléssel. A terápia megkezdésekor a páciens jobb csuklójára helyeztünk egy készüléket, attól függően, hogy melyik kézben tartja az ütöt, majd miután megtörtént a készülékek felhelyezése, különböző méréseket végeztünk el egy szakorvos segítségével, az ütő mozgatásával kapcsolatban, $X, Y, Z$ tengelyek mentén. Az első mérés az ütő $X$ tengely körüli forgatása volt, ugyanis azt vettem észre, hogy a páciens amíg koncentrál gyakran forgatja az ütőt a kezében.

A diagramon egymásra vannak helyezve a rehabilitáció megkezdése előtti és a rehabilitáció végén kapott eredmények diagramjai. A rehabilitáció megkezdése előtti értékeket piros színü diagram, a rehabilitáció végén kapott eredményeket a kék színü diagram mutatja. Az itt látható felső tengely mutatja a $Z$ tengelyirányban történő elmozdulást, vagyis a gyorsulások mértékét, a középső tengely az $\mathrm{X}$ tengelyirányban történő elmozdulás mértékét, valamint az alsó tengely az $\mathrm{Y}$ irányba történő elmozdulást, vagyis a gyorsulás mértékét.

\subsection{Az ütő forgatása}

A rehabilitáció megkezdése elött a mérés elemzése során láthatóvá vált a gyorsulásmérő diagramján, hogy az adott tengely körüli forgatás értéke ( $X$ tengely) megközelítöleg nulla. Ez azt jelenti, hogy szinte tökéletesen forgatta a páciens a kezében az ütőt. A másik két tengely irányában az elmozdulás pedig közel szinusz és közel koszinuszgörbét rajzol ki (4.ábra). Ez nem hat ki a forgatás pontosságára, csak a gyorsulást mutatja a forgatás közben.

A rehabilitáció végén azt tapasztaltam, hogy az ütő forgatásának mértéke az adott $X$ tengelyre, nagyon kevés mértékben változik, szinte változatlan. Mondhatjuk, hogy megközelítöleg nulla maradt, de a másik két tengely irányában elég nagy mértékben változott a sebesség, vagyis azt a következtetést vontam le, hogy a páciens gyorsabban forgatta a kezében az ütőt, mint a rehabilitáció elején. Ezzel beigazolódott az a feltevésem, miszerint a rehabilitációk eredményesek. $A z Y$ és $Z$ 
tengelyirányú görbe alakja nem változott, most is megközelítöleg szinusz és koszinuszgörbét rajzoltak ki.

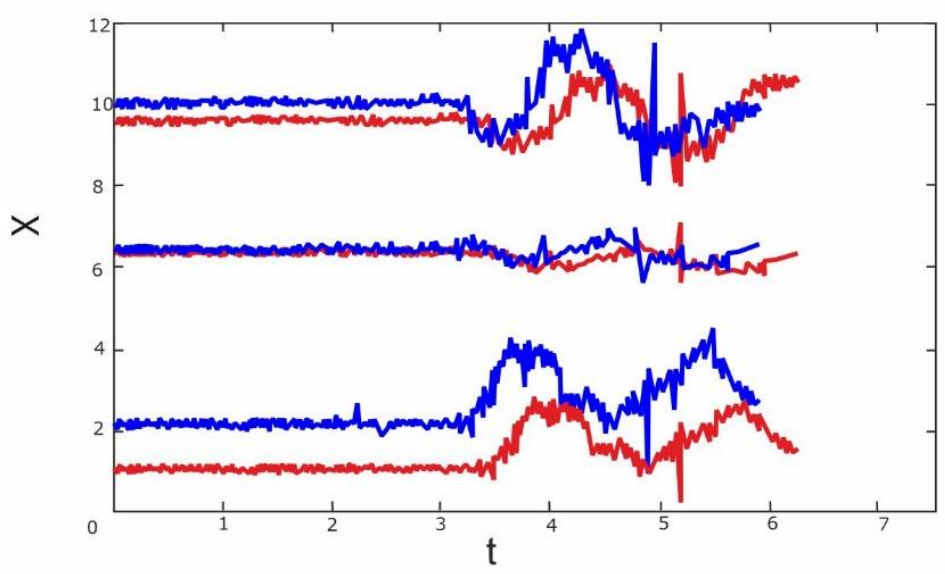

\section{A rehabilitáció megkezdése előtt A rehabilitció után}

\section{4. ábra: Az ütö X tengely körüli forgatása}

\subsection{A suhintás}

Ahhoz, hogy a kutatás eredménye biztos megfelelő legyen, a továbbiak során két, másik mozdulatot választottunk vizsgálatra, amelyeket a terápiában résztvevő páciens elvégzett, ezek pedig a suhintás és a szerva.

A bemutatott páciens esetében a suhintás mozdulata során kivehető, hogy a rehabilitáció elején elég kis mértékủ a három tengelyirányú kimozdulása a gyorsulásmérőnek (5.ábra). Ennek a mozdulatnak a során több ugyanolyan, ismételt mozdulat látható, amelyek megközelítöleg egyformák, tehát megközelítőleg ugyanolyan hosszúak és ugyanolyan gyorsaságúak voltak egymáshoz viszonyítva.

A rehabilitáció végén megismételtettük a suhintás mozdulatsorát a pácienssel. Az ábrából kitűnik, hogy a suhintás mozdulata erősebb. Ez abból látszik, hogy a három tengelyirányba történő gyorsulásmérő adatai sokkal nagyobbak, mint a rehabilitáció elején, ami arra utal, hogy a páciens ütése is erősebb, tehát fejlődött. További érdekesség, hogy az ismételt mozdulatsor során azonos idő alatt a több ütést tudott a páciens megismételni, ami szintén azt bizonyítja, hogy ütései gyorsabbak, mint a rehabilitáció elején voltak. 


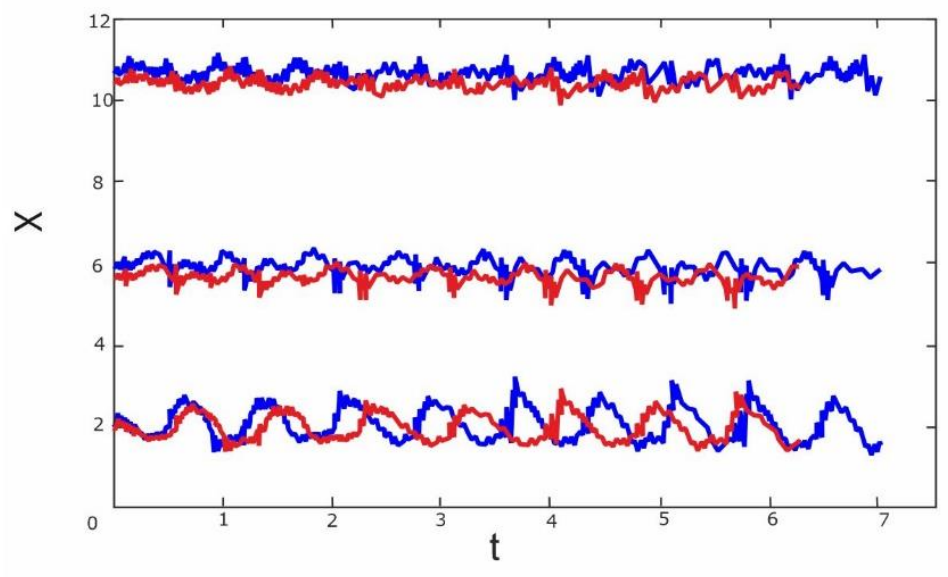

A rehabilitáció megkezdése előtt

A rehabilitció után

5.ábra: Suhintás

\subsection{A szerva}

A következő mozdulat, ami elemzésre került, az a szerva volt, ugyanis ez az egyik kulcsfontosságú mozdulat, ami erre a sportra jellemző és könnyen kivitelezhető még olyan esetben is, amikor a rehabilitációban résztvevő páciensnek nincs partnere, akivel a rehabilitációt végezheti.

Amikor a földröl visszapattant labdát a beteg elütötte, pont az történt mintha feldobta volna a labdát. A szerva mozdulatának kivitelezése úgy zajlott, hogy egy labdát függölegesen elejtettünk szervára. Mint ahogyan az a 6.ábrából kitünik ezzel egy olyan helyzetet valósítottunk meg, ahol az elütés előtti pillanatokban a páciens alig végzett mozgást, sőt szinte mozdulatlan. Ez megközelítőleg 4,2 másodpercig tartott, majd elütötte a labdát. Ennyi idő kellett ahhoz, hogy az elengedett labda leérjen a földre, majd visszapattanva az ütő magasságába felérjen és a páciens el tudja ütni. Mivel ilyen esetben, amikor a labda kisebb sebességgel találkozott az ütővel, kisebb mértékű volt a becsapódása is. Egyértelmü, tehát, hogy a labda sebessége befolyásolja a különböző ütéseket.

A rehabilitáció végén elvégeztük ugyanezt a mérést és azt látjuk a kapott diagramból, hogy a labda a föltől való visszapattanásának ideje megközelítőleg azonos a rehabilitáció elején történő visszapattanásának idejével. Ez most megközelítőleg 4 másodperc. A gyorsulásdiagram nagyon nagy mértékben hasonlít a rehabilitáció elején mért diagram alakjára, de az ütő gyorsasága ebben az esetben is sokkal nagyobb lett. 


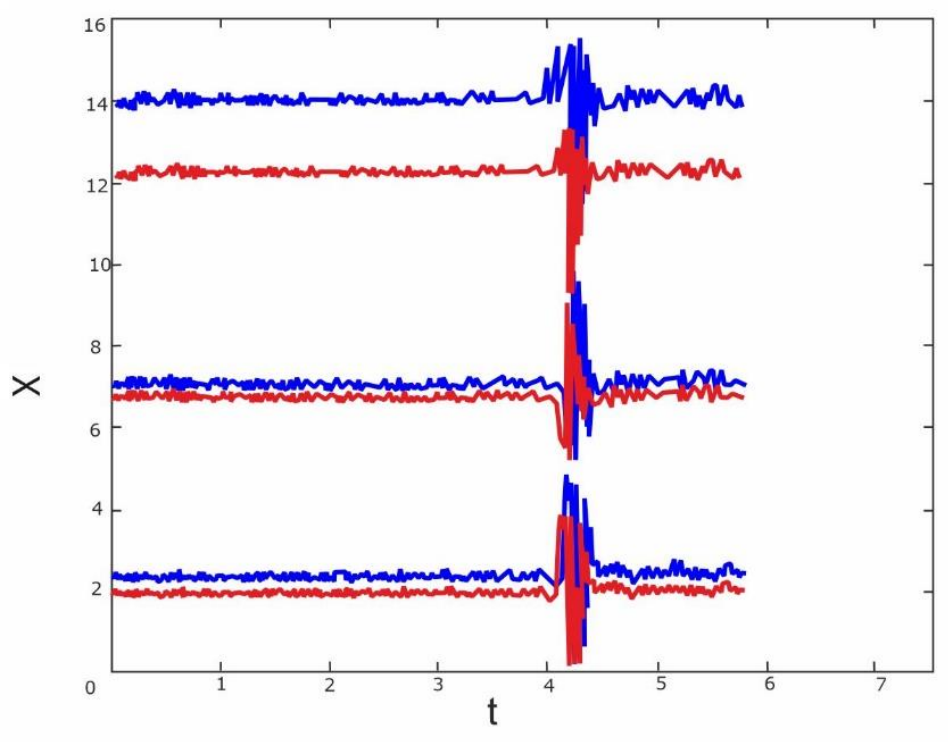

A rehabilitáció megkezdése előtt A rehabilitció után

6.ábra: Szerva

\section{6. Összegzés}

Amikor összehasonlítjuk a rehabilitáció megkezdése előtti és a rehabilitáció utáni mérések eredményeit, akkor azt láthatjuk, hogy az ütő $X$ tengely körüli forgatása esetén mindhárom tengelyiránynak igen hasonló az alakja (4.ábra). Ezzel azt mondhatjuk, hogy a páciens ütéstechnikája nem változott. Ez pozitív, ugyanis nem ez volt a cél. Viszont, ha a három tengelyirány gyorsulását nézzük, elég nagy változás következik be, ugyanis a rehabilitáció végére magasabb értékeket kapunk A páciens gyorsabban forgatta a kezében az ütőt, tehát mindenképp jelentösen fejlődött. A fejlődés mértéke $60 \%$, a terápia megkezdése előtti állapotához képest.

De az ütö forgatásának ideje is szignifikánsan rövidül a rehabilitáció végén, ami szintén azt támasztja alá, hogy a páciens gyorsabban, ügyesebben forgatta az ütőt a kezében.

A suhintás során kapott két diagrammot egymásra helyezzük, akkor megfigyelhetjük, hogy a három tengelyirány egyikében sem áll be nagyobb változás, ami az ütő gyorsulását illeti (5.ábra). Ez azt jelenti, hogy nem értünk el kiemelkedő fejlődést ebben a mozdulatsorozatban, de szembeötlő az a tény, hogy azonos időtartam alatt a páciens a rehabilitáció végére több mozdulatot tudott végrehajtani, mint a rehabilitáció megkezdése előtt.

Ebből arra a következtetésre juthatunk, hogy amíg az ütés gyorsaságában nem tudtunk magasabb értékeket kapni, addig a mozdulat ismétlése gördülékenyebben és könnyebben ment végbe, vagyis a páciens fejlődött itt is. A páciens fejlődése, ennél az ütésformánál is jelentős, azaz $60 \%$-os javulást mutat a kezdeti állapothoz képest.

Az utolsó elemzett ütésfajta a szerva volt. Amikor egymásra helyezzük a diagramokat egyböl kivehető, hogy a mozdulat megközelítőleg ugyanakkor kezdődik, vagyis a labda leejtése a földre, majd annak visszapattanása a földröl szinte ugyanakkor történik (6.ábra). A két diagram összehasonlításakor szembetűnik, hogy a szerva mozdulata gyorsabban megy végbe a rehabilitáció végére és a mindhárom tengelyirányú változásban is sokkal magasabb gyorsulási értékeket kapunk. Ebböl szintén azt a következtetést vonhatjuk le, hogy a páciens fejlödött. Ennek a fejlödésnek a mértéke $61,4 \%$ a kezdeti állapothoz képest. 
Ha minden ütésforma $X, Y$ és $Z$ tengelyirányú gyorsulásait összegezzük, majd átlagoljuk ezeket a gyorsulásokat (1.táblázat), akkor azt láthatjuk a 35-ös sorszámú páciens minden ütésformánál fejlődött, de a legnagyobb változás a szervánál következett be. Itt érte el a legnagyobb fejlődést, míg a legkisebb mértékủ fejlődést az ütő tengely körüli forgatásánál tapasztalunk.

\begin{tabular}{|l|l|l|l|l|l|l|}
\hline & \multicolumn{3}{|l|}{ A rehabilitáció megkezdése előtt } & \multicolumn{2}{l|}{ A rehabilitáció után } \\
\hline Sorszám & $\begin{array}{l}\text { Az ütö } \\
\text { tengelykörüli } \\
\text { forgatása }\end{array}$ & Suhintás & Szerva & $\begin{array}{l}\text { Az ütö } \\
\text { tengelykörüli } \\
\text { forgatása }\end{array}$ & Suhintás & Szerva \\
\hline 35. & 5,633 & 6,023 & 7,001 & 9,013 & 9,637 & 11,302 \\
\hline
\end{tabular}

\section{1.táblázat}

Ha ezeket a kapott eredményeket összehasonlítjuk a szakorvos és a gyógyterápiás szakember által meghatározott 40\%-os fejlődési szinttel, amit a klasszikus terápiák során eddig elértek, akkor esetünkben a fejlődési szint jelentősen magasabb.

Ez arra enged következtetni, hogy az általunk végzett terápia eredményesebb az eddig használatos, azaz klasszikus terápiánál.

\section{Köszönetnyilvánítás}

Köszönettel tartozunk a kutatás támogatásáért, amely az EFOP-3.6.1-16-2016-00006 „A kutatási potenciál fejlesztése és bővítése a Neumann János Egyetemen" pályázat keretében valósult meg. A projekt a Magyar Állam és az Európai Unió támogatásával, az Európai Szociális Alap társfinanszírozásával, a Széchenyi 2020 program keretében valósul meg.

\section{Irodalomjegyzék}

[1] O. Chipara, C. Lu, T. C. Bailey, and G.-C. Roman,BReliable patient monitoring: A clinical study in a step-down hospital unit,[Dept. Comput. Sci. Eng., Washington Univ.St. Louis, St. Louis, O, Tech. Rep.WUCSE-2009-82, Dec. 2009.

[2] J. Ko, J. Lim, Y. Chen, R. Musaloiu-E., A. Terzis, G. Masson, T. Gao, W. Destler, L. Selavo, and R. Dutton,BMEDiSN: Medical emergency detection in sensor networks, [ACM Trans. Embedded Comput. Syst., vol. 10, no. 1, pp. 11:1-11:29, 2010, article 11.

[3] D. Malan, T. Fulford-Jones, M. Welsh, and S. Moulton,BCodeBlue: An ad hoc sensor network infrastructure for emergency medical care,[inProc. MobiSys/ Workshop Appl. Mobile Embedded Syst., Jun. 2004, pp. 12-14.

[4] T. Gao, C. Pesto, L. Selavo, Y. Chen, J. Ko, J. Lim, A. Terzis, A. Watt, J. Jeng, B. Chen, K. Lorincz, and M. Welsh,BWireless medical sensor networks in emergency response: Implementation and pilot results, [in IEEE Int. Conf. Technol. Homeland Security,2008, pp. 187-192.

[5] Virone, A. Wood, L. Selavo, Q. Cao, L. Fang, T. Doan, Z. He, and J. A. Stankovic, Ban advanced wireless sensor network for health monitoring,[in Proc. Transdisciplinary Conf. Distrib. Diagnosis Home Healthcare, Apr. 2006, pp. 95-100.

[6] K. Patrick, "A tool for geospatial analysis of physical activity: Physical activity location measurement system (PALMS)," NIH GEI project at the University of California at San Diego, 2007.

[7] S. Kumar, "Autosense," NIH GEI project at The University of Memphis, 2007.

[8] https://www.shimmersensing.com/products/shimmer3 [Megtekintés: 07-Június-2017].

[9] https://es.scribd.com/document/55750053/49CA4d01 [Megtekintés: 06-Június-2017].

[10] https:// www.shimmersensing.com [Megtekintés: 25-Július-2017].

[11] Alargić $P$, Kaurin T, "Digitalna forenzika mobilnih uređaja korišćenjem JTAG interfejsa”, Infoteh-Jahorina Vol. 12, March 2013. 